\title{
Palynological Data of Cupressaceae Family in Elbasan Region, Albania
}

\author{
1,3Admir Jançe \\ 2Gëzim Kapidani \\ ${ }^{3}$ Blerina Pupuleku \\ ${ }^{3}$ Nikoleta Kallajxhiu \\ ${ }^{3}$ Anxhela Dauti \\ 1"Albanian University", Tiranë, Albania \\ 2Tirana University, Tiranë, Albania \\ 3University"Aleksander Xhuvani" Elbasan, Albania \\ Email: adi_jance@yahoo.it
}

\section{Doi:10.5901/ajis.2015.v4n2s2p204}

\section{Abstract}

The study is performed in Elbasan city. A lot of biological studies have been realized in this region during two last decades' periods. This city is situated in the middle of Albania. It is one of the biggest cities of Albania, with a population of around 100,000 and an area of $1,290 \mathrm{~km}^{2}$. It lies down along Shkumbini River in the District of Elbasan at elevation $150 \mathrm{~m}$. This study provides some palynological data about the dispersion of Juniperus genus, part of Cupressaceae family in depositions of last XX centuries (last historic period of New Holocene, last Quaternary, in the area where is situated Elbasan. The aim of this paper is to present the correlation between the depth and dispersion of Cupressaceae family on different periods of time. For this purpose we took some samples from various layers of soil, starting from the surface to four meters depth. Palynological data for this family were provided for the first time in the Albania's palynological literature. Observations, counting and photos of palynomorphs it was carried on using light microscopes, magnification up to 1000x. According to the analyses of these samples we found out several interesting data that showed clearly the correlation between the depth and number of spores and pollens for this family.

Keywords: Palynological, New Holocene, spore, pollen, Cupressaceae Family.

\section{Introduction}

Palynology is an Interdisciplinary Science, connected to biological sciences and geology, particularly of botanical science. (Kapidani, 1996; Pacini \& Franchi, 1978).

Palynology is the science that studies the pollens, spores, acritarchs, chitinozoans, scolecodonts, during the organic sediments formation, above all this science includes the study of current and fossil palynoforms. (Fegri, 1957; Davis, 1999).

The given material presents paleopalynological problems of Holocene deposits in Elbasan city. There aren't any studies by neither native or foreign authors for spore and pollen content data in Quaternary deposits in our country and plant microfossils have not been studied previously from any of the localities in Elbasan. (Kapidani, 1996; Kapidani \& Jançe, 2004).

The study provides the factors which have their impact on the potential transformation of the flora in Elbasan city, focused on evolution of Cupressaceae family. (Kapidani \& Jançe, 2004; Moore \& Webb, 1978; Shalla, 1983; Jance \& Kapidani, 2011; Forest et al., 1999).

This study in Quaternary deposits also provides important information about the reconstruction of paleoflora, paleoclimate, stratygraphy of the Holocene, etc.

The quantitative data through spores and pollens variety of Cupressaceae family deposited on the underground, shows the direction of evolution of this family mentioned in the study. (Kapidani, 1996; Kapidani \& Jançe, 2004; Muhameti et al., 1984). 


\section{Materials and methods}

During this study we have taken 16 soil samples, starting from 4 meters depth to $0.25 \mathrm{~m}$. The distance between the sampling stations is $0.25 \mathrm{~m}$. The sampled area was a hole with these dimensions: (length) 20m; (width) 18m; (depth) $4.5 \mathrm{~m}$. We collected sediments that contained an assemblage of fossil pollen and spores.

The soil sampling is based on Erdtman method (Erdtman, 1960; Erdtman, 1969). Erdtman acetolyze method consists on processing the material by mixing concentrated acetic acid (glacial) with sulfuric acid $\left(\mathrm{H}_{2} \mathrm{SO}_{4}\right)$ in 9:1 rapport. In order to get better results first mix $1 \mathrm{~cm}^{3}$ soil with $10 \mathrm{ml} \mathrm{KOH} \mathrm{(10 \% ).} \mathrm{After} \mathrm{that} \mathrm{we} \mathrm{cleaned} \mathrm{it} \mathrm{with} \mathrm{distillated} \mathrm{water,} \mathrm{and}$ then we mixed it with acetolyze solution, until a neutral environment is obtained.

After that the precipitate is mixed with glycerin and observed on 1000x magnification Biolamp microscope.

The acetolyze method is widely used in palynology, it gives better visibility over the spores and pollens compared with the other methods used during the microscopic observation process. (Aleshina, 1964; Erdtman, 1969; Kapidani, 2005; Jançe \& Kapidani, 2011; Moore \& Webb, 1978; Davis, 1999). We then use this method to assess the paleoclimate and paleoelevation represented by the assemblage and will discuss the results in terms of their implications for the uplift history of the Elbasan region.

\section{Results and Discussions}

On table 1 are presented the data about the number of spores for Cupressaceae family according to the depth. Also is presented and the total number of spores for this family.

The maximum number of spores of Cupressaceae family (152 spores per sample) is taken in $0.25 \mathrm{~m}$ of depth while the minimum number, 53 spores, is taken in the bottom respectively $4 \mathrm{~m}$ of depth.

Table 1. Number of spores according to the depth

\begin{tabular}{|c|c|c||}
\hline \hline Sample & Depth (meters) & Number of spores (Cupressaceae) \\
\hline 1 & 4 & 53 \\
\hline 2 & 3.75 & 70 \\
\hline 3 & 3.5 & 73 \\
\hline 4 & 3.25 & 87 \\
\hline 5 & 3 & 89 \\
\hline 6 & 2.75 & 103 \\
\hline 7 & 2.5 & 120 \\
\hline 8 & 2.25 & 142 \\
\hline 9 & 2 & 142 \\
\hline 10 & 1.75 & 144 \\
\hline 11 & 1.5 & 139 \\
\hline 12 & 1.25 & 134 \\
\hline 13 & 1 & 132 \\
\hline 14 & 0.75 & 141 \\
\hline 15 & 0.5 & 152 \\
\hline 16 & 0.25 & 1780 \\
\hline \multicolumn{2}{|c|}{ Total number of spores } & \\
\hline
\end{tabular}

On figure 1 is clearly shown the upward trend of number of spores of Cupressaceae family from the bottom near to the surface, also is clearly shown the increasing number of spores for this family above all near to the surface.

Based on the data presented in table 1 and figure 2 the spore's total number of Cupressaceae family is 1780 spores. (Figure 2):

In sample 15 and 16, the number of spores of Cupressaceae family undergoing an immediate increase. (Photo 1, 2). The data show that the increase of the representative's presence of family Cupressaceae near to the surface should be associated with human impact on the cultivation of this family plant. (Group of authors, 2003). 


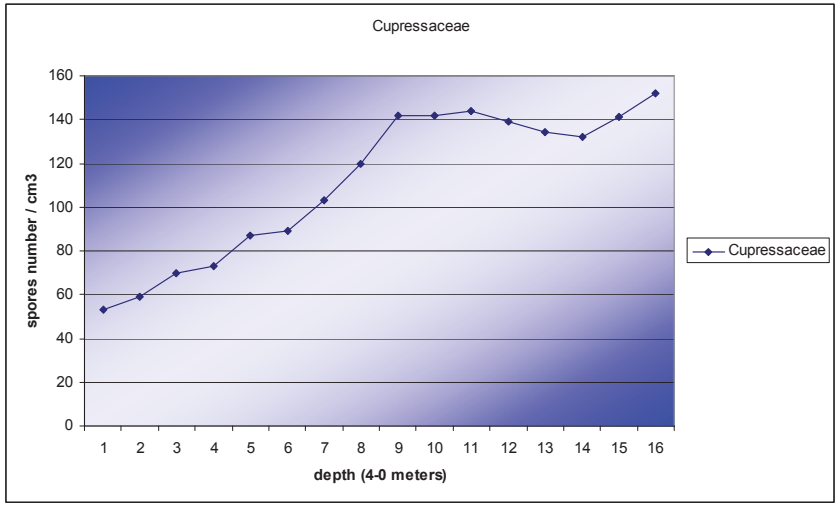

Figure 1. The spore's dispersion of Cupressaceae family according to the depth

As shown in Figure 1, all Cupressaceae family forms, from the bottom toward the surface is increasing their overall presence. One of the reasons for this increase may be related to the fact that new forms of pollen are stored better than older ones to meet the depths samples. But in this storage may have affected the ecological factors.

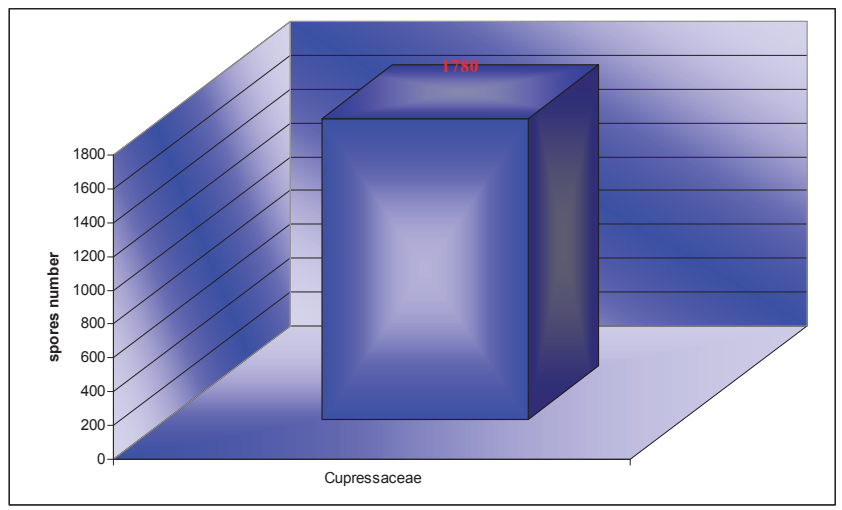

Figure 2. The total number of spores according to Cupressaceae family

So there is an upward trend, which is associated with the best chance of saving them from the bottom to the surface deposits.

Interesting is the fact that the samples matched depths approximately 2-1.5 m with years 900 to 1200 , the number of pollen is smaller than in years about it, despite the general trend of their growth.

Unable to find data on climatic factors, are supported in medieval history of Albania (Hasanaj et al., 2004), in which it is alleged that this period was associated with wild wars of extermination of the Bulgarian and Serbian occupation where the population the area is greatly reduced and the city loses the economic importance.

Given the presence of particles carbon micro grains in the sample we believe that herbal landscape of the city of Elbasan, as a result of the war would have suffered devastation from massive burns and consequently for its reconstruction probably had plenty of time.

Elbasan city crowns today is mainly composed of olive plantations associated with fruit trees and a rich vegetation grass, the major part of which is cultivated. The impact of human activity is the main cause during the crowns transformations of Elbasan city. 


\section{Conclusions}

1. The the representatives of Cupressaceae family are present for depth 4 meters up near the surface 0.25 .

2. The spore's number of Cupressaceae family from the bottom toward the surface is increasing their overall presence.

3. Since in Elbasan region not had climate and natural factors that have influenced in the vegetation change; we are mostly of the opinion that vegetation changes reported over the years are mainly related to the impact of human hand.

4. In all depths samples meet particles of carbon micro grains as evidence of fires.

\section{References}

Aleshina, L.A. (1964). O plici tikvenih. - Bot. Zhurnal, Moskva, 12: 1773-1778.

Group of authors. (2003). Elbasani Enciklopedi. - Sejko, Elbasan, 750 pp.

Erdtman, G. (1960). The acetolysis method. A revised description. Svensk Botanisk Tidskrift, 54: 561-564.

Erdtman, G. (1969). Handbook of palynology. An introduction to the study of pollen grains and spores. Hafner Publishing Company, New York, $486 \mathrm{pp}$.

Fegri, K. (1957). Morfologia pilci dija prakticeskih cellej. - Bot. Zhurnal, Moskva, 1: 20-31.

Kapidani, G. (1996). Bazat e Palinologjisë. - Sejko Infoservis, Elbasan, 230 pp.

Kapidani, G. (2005). Fjalori i Terminologjisë Palinologjike. - Sejko, Elbasan, 149 pp.

Kapidani, G. \& Jançe, A. (2004). Të dhëna të pjesshme mbi studimin e sporeve dhe poleneve në depozitimet e Kuaternarit në qytetin e Elbasanit. - Buletini Shkencor UE, Elbasan, 1: 58-65.

Moore, P.D. \& Webb, J.A. (1978). An illustrated Guide to Pollen Analysis. - Hodder and Stoughton, London, 133 pp.

Muhameti, P. \& Gjani, E. \& Roqi, R. (1984). Palinostratigrafia e depozitimeve të Tortonianit në pjesën lindore të Ultësirës pranë Adriatikut në bazë të studimit të sporopoleninit. - Buletini Nafta dhe Gazi, Fier, 204 pp.

Davis, O.K. (1999). Preliminary pollen analysis of Neogene and Quaternary sediment of The Great Salt Lake, U.S.A. - Proceedings Pliocene Conference, AASP Contribution, Arizona, 34: 227-240.

Pacini, E. \& Franchi, G.G. (1978). II polline: Biologia e Aplicazioni. - Quaderni di biologia, Bologna, 12: 8-53.

Shalla, M. et al. (1983). Gjeologjia e Shqipërisë. - Shtëpia Botuese "Naim Frashëri", Tiranë, 343 pp.

Jançe, A. \& Kapidani, G. (2011). Palynological data of Compositae and Umbelliferae families during Holocene Period in Elbasan city - J. Int. Environmental Application \& Science, (JIEAS - 2011), Vol. 6, No. 5: 729-733.

Forest C. E. et al. (1999). Paleoaltimetry incorporating atmospheric physics and botanical estimates of paleoclimate. - Bulletin of the Geological Society of America 111: 497-511

Jançe, A. \& Kapidani, G. (2011). Palynological data of Compositae and Umbelliferae families during Holocene Period in Elbasan city - J. Int. Environmental Application \& Science, (JIEAS - 2011), Vol. 6, No. 5: 729-733.

Hasanaj C., Islami S., Korkuti M., Prendi F., Anamali S., Shukriu E. (2004). Historia e Shqipërisë: 667. www.home.no/dukagjin

Appendix 1. Microscopic photos

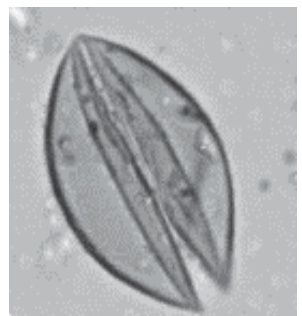

Ph.1. Juniperus Typ Pollen

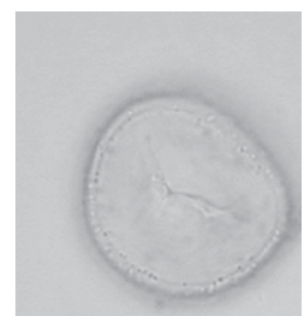

Ph.2. Cupressus Typ Pollen 